Jurnal Mahasiswa BK An-Nur : Berbeda, Bermakna, Mulia

Volume 7 Nomor 1 Tahun 2021

Tersedia Online: https://ojs.uniska-bjm.ac.id/index.php/AN-NUR

p-ISSN. 2460-9722 | e-ISSN. 2622-8297

\title{
UPAYA GURU BIMBINGAN DAN KONSELING DALAM MEMOTIVASI BELAJAR ANAK NELAYAN DI SMP NEGERI 1 PULAU LAUT TANJUNG SELAYAR
}

\author{
Dina Aida Audria ${ }^{1}$, Sultani $^{2}$, Didi Susanto ${ }^{3}$ \\ Program Studi Bimbingan dan Konseling Fakultas Keguruan dan Ilmu Pendidikan Universitas Islam \\ Kalimantan Muhammad Arsyad Al Banjari Banjarmasin \\ E-mail: audriadina@gmail.com/No. HP 082354169985
}

\begin{abstract}
ABSTRAK
Upaya guru bimbingan dan konseling dalam pelaksanaan layanan konseling kelompok dapat meningkatkan motivasi siswa untuk terus melaksanakan kewajibannya sebagai seorang pelajar dan menggapai cita-citanya, dengan memberikan dorongan kepada peserta didik untuk terus belajar. Penelitian ini bertujuan untuk mengetahui gambaran motivasi belajar anak nelayan di SMP Negeri 1 Pulau Laut Tanjung Selayar, untuk mengetahui faktor rendahnya motivasi belajar anak nelayan di SMP Negeri 1 Pulau Laut Tanjung Selayar, untuk mengetahui upaya guru bimbingan dan konseling dalam meningkatkan motivasi belajar anak nelayan di SMP Negeri 1 Pulau Laut Tanjung Selayar. Penelitian ini adalah penelitian kualitatif, subjek penelitian ini siswa kelas VIII SMP Negeri 1 Pulau Laut Tanjung Selayar yang memiliki motivasi belajar rendah. Teknik pengumpulan data dalam penelitian ini menggunakan teknik wawancara dan dokumentasi. Hasil dari penelitian ini menggambarkan layanan konseling kelompok yang dilaksankan untuk meningkatkan motivasi belajar siswa sudah dikatakan berhasil karena dapat mengatasi permasalahan siswa dan meningkatkan motivasi belajar pada anak nelayan di SMP Negeri 1 Pulau Laut Tanjung Selayar. Hasil penelitian ini dapat disimpulkan bahwa terdapat beberapa anak nelayan yang memiliki motivasi belajar yang rendah. Upaya guru Bimbingan dan konseling dalam pelaksanaan layanan konseling kelompok dapat meningkatkan motivasi belajar pada anak nelayan di SMP Negeri 1 Pulau Laut Tanjung Selayar.
\end{abstract}

Kata Kunci: belajar; konseling; motivasi; siswa; upaya

\begin{abstract}
The efforts of guidance and counseling teachers in the implementation of group counseling services can increase student motivation to continue to carry out their obligations as a student and achieve their goals, by providing encouragement to students to continue learning. This study aims to determine the description of the learning motivation of fishermen children in SMP Negeri 1 Pulau Laut Tanjung Selayar, to determine the factor of the low learning motivation of fishermen children in SMP Negeri 1 Pulau Laut Tanjung Selayar, to find out the efforts of guidance and counseling teacher to increase learning motivation for fishermen children in Indonesia Junior High School 1 Sea Island Tanjung Selayar. This research is a qualitative research, the subject of this research is the VIII grade students of SMP Negeri 1 Pulau Laut Tanjung Selayar who have low learning motivation. Data collection techniques in this study using interviews and documentation. The results of this study illustrate that group counseling services implemented to increase student learning motivation have been said to be successful because they can overcome student problems and increase learning motivation in fishermen's children in SMP Negeri 1 Pulau Laut Tanjung Selayar. The result of this study can be concluded that there are some fishermen's children who have low learning motivation. The efforts of guidance and counseling teacher in the implementation of group counseling services can increase learning motivation for fishermen's children in SMP Negeri 1 Pulau Laut Tanjung Selayar.
\end{abstract}

Keywords: learns; counseling; motivation; students; effort

Dipublikasikan Oleh :

UPT Publikasi dan Pengelolaan Jurnal

Universitas Islam Kalimantan Muhammad Arsyad Al-Banjari Banjarmasin 


\section{Dina Aida Audria ${ }^{1}$, Sultani $^{2}$, Didi Susanto ${ }^{3}$ \\ Jurnal Mahasiswa BK An-Nur : Berbeda, Bermakna, Mulia \\ Volume 7 Nomor 1 Tahun 2021 \\ Tersedia Online: https://ojs.uniska-bjm.ac.id/index.php/AN-NUR \\ p-ISSN. 2460-9722 | e-ISSN. 2622-8297}

\section{PENDAHULUAN}

Undang-undang Nomor 20 Tahun 2003 mengenai Sistem Pendidikan Nasional, pendidikan bertujuan mengembangkan potensi peserta didik agar menjadi manusia yang beriman dan bertakwa kepada Tuhan Yang Maha Esa, berakhlak mulia, sehat, berilmu, cakap, kreatif, mandiri, dan menjadi warga negara yang demokratis serta bertanggung jawab.

Pendidikan merupakan kata kunci yang perlu kita terapkan untuk mewujudkan sumber daya manusia yang seutuhnya, yang mampu menjawab perkembangan teknologi informasi dan komunikasi yang semakin deras dalam kehidupan berbangsa dan bernegara. Pendidikan yang baik dan bermutu akan melahirkan putera puteri terbaik bangsa yang memiliki potensi, kreatif, inovatif, berakhlak, bakat yang tumbuh dan berkembang dalam segala bidang kehidupan, mental serta fisik yang kuat.

Pendidikan suatu daya upaya untuk memajukan bertumbuhnya budi pekerti (kekuatan batin, dan karakter), pikiran (intelek) dan tubuh anak, dalam rangka kesempurnaan hidup dan keselarasan dengan dunianya (Ki Hajar Dewantara, 2016: 9). Terdapat tiga poin penting yang dapat ditarik dari definisi di atas, yaitu budi pekerti atau akhlak dalam kehidupan sehari-hari, pikiran atau cara berpikir dan tubuh atau cara kita bersikap pada lingkungan sekitar.

Melalui pendidikan budi pekerti, manusia diharapkan memiliki karakter yang kuat. Karakter tersebut hendaklah mewarnai kehidupan yang baik melalui tutur kata, sikap, atau perbuatan yang ditujukan terhadap dirinya sendiri, orang lain maupun lingkungan sekitar. Perilaku yang baik terhadap orang lain dan lingkungan sekitar merupakan salah satu manfaat dalam pendidikan.

Manfaat pendidikan tidak hanya untuk mengembangkan potensi yang ada dalam diri peserta didik, mengatur pola pikir dan membantu menyelesaikan masalah yang dihadapinya, melainkan juga memberi manfaat untuk orang lain. Manfaat pendidikan dapat di terapkan pada lingkungan sekolah, lingkungan masyarakat dan keluarga. Khususnya pada lingkungan sekolah, manfaat yang didapat oleh peserta didik adalah dari tenaga pendidik yang disampaikan melalui proses belajar mengajar. Pada pembelajaran banyak sekali ilmu yang bisa didapat oleh peserta didik tetapi akan banyak juga kelemahan yang terdapat dalam proses tersebut.

Terdapat beberapa kelemahan yang terjadi pada dunia pendidikan seperti rendahya efektifitas pendidikan, rendahnya kualitas sarana prasarana, rendahnya kualitas pengajar, rendahnya kesejahteraan pengajar, rendahnya prestasi siswa, kurangnya pemerataan kesempatan pendidikan, mahalnya biaya pendidikan, dan rendahnya relevansi pendidikan dengan kebutuhan. (Tim Penulis, 2019: 20)

Kelemahan-kelemahan dalam pendidikan terjadi karena beberapa faktor, diantaranya kurangnya perhatian guru kepada peserta didik, kurangnya bahan ajar yang disampaikan kepada peserta didik, kurangnya kualitas para pengajar, tidak efektifnya proses belajar mengajar, kurangnya perhatian peserta didik terhadap pembelajaran, kurangnya motivasi peserta didik terhadap pembelajaran, terbatasnya sarana dan prasarana pendidikan yang ada di sekolah.

Beberapa kelemahan di atas merupakan sebagian besar masalah yang terjadi hampir disetiap sekolah, terutama pada daerah-daerah terpencil yang kurang perhatian dari pemerintah. Upaya yang dapat dilakukan untuk meningkatkan pendidikan yang baik, yaitu dengan meningkatkan kualitas pengajar, memperbanyak materi yang disampaikan sesuai kurikulum yang telah ditetapkan pemerintah, peningkatan kualitas proses pembelajaran, meningkatkan sarana dan prasarana, serta terus memotivasi para peserta didik untuk semangat belajar.

Peningkatan kualitas belajar siswa perlu adanya motivasi belajar, motivasi sangat penting dalam kegiatan belajar mengajar, sebab adanya motivasi mendorong semangat belajar dan sebaliknya kurang adanya motivasi akan melemahkan semangat belajar. Seorang siswa yang belajar tanpa motivasi atau kurang motivasi, tidak akan berhasil dengan maksimal.

Motivasi memiliki peranan penting dalam pendidikan, karena motivasi adalah pendorong untuk siswa mampu memiliki prestasi belajar yang baik dari potensi-potensi yang dimilikinya. Siswa juga mampu menggunakan potensinya untuk menciptakan motivasi di dalam dirinya maka guru dan konselor sekolah diharapkan mampu untuk mengembangkan motivasi yang tepat pada siswa.

Guru diharapkan dapat mencairkan suasana belajar senyaman mungkin untuk meningkatkan motivasi belajar siswa. Siswa yang memiliki motivasi belajar karena didorong oleh kekuatan dari dalam diri dan dari luar dirinya berupa keinginan, perhatian, kemauan, cita-cita dan persaingan belajar. Dorongan motivasi belajar pada lingkungan sekolah harus diperhatikan oleh guru sebagai pendidik bagi siswa di sekolah. Sedangkan, untuk di lingkungan sekitar dan keluarga membutuhkan perhatian dari orang tua dan masyarakat.

Dipublikasikan Oleh :

UPT Publikasi dan Pengelolaan Jurnal

Universitas Islam Kalimantan Muhammad Arsyad Al-Banjari Banjarmasin 


\section{Dina Aida Audria ${ }^{1}$, Sultani $^{2}$, Didi Susanto ${ }^{3}$ \\ Jurnal Mahasiswa BK An-Nur : Berbeda, Bermakna, Mulia \\ Volume 7 Nomor 1 Tahun 2021}

Tersedia Online: https://ojs.uniska-bjm.ac.id/index.php/AN-NUR

p-ISSN. 2460-9722 | e-ISSN. 2622-8297

Setiap individu pada dasarnya mengalami peristiwa belajar dalam hidupnya, agar mampu mengubah atau mengembangkan perilaku seseorang menjadi lebih baik. Pengembangan perilaku siswa termasuk untuk meningkatkan motivasi, diperlukannya peran seorang guru salah satunya guru bimbingan dan konseling.

Peran seorang guru bimbingan dan konseling sangat penting dalam kegiatan belajar mengajar di sekolah. Guru bimbingan dan konseling pada lingkup sekolah menengah pertama akan terlihat lebih aktif di peran-peran yaitu dalam pelaksanaan orientasi siswa, aktivitas observasi perilaku siswa, pelaksanaan konseling, konsultasi orang tua siswa, penempatan kelas siswa berdasarkan kebutuhan siswa, dan hal-hal mengenai perkembangan siswa. Ide mengenai peran tersebut dilihat dari deskripsi mengenai aktivitas sehari-hari yang dialami oleh guru bimbingan dan konseling. (Robert, 2016: 93)

Bimbingan dan konseling merupakan pelayanan bantuan untuk peserta didik, baik secara perorangan atau kelompok agar mandiri dan bisa berkembang secara optimal, dalam bimbingan pribadi, bimbingan sosial, belajar maupun karir melalui berbagai jenis layanan dan kegiatan pendukung lainnya berdasarkan norma-norma yang berlaku. Dalam bimbingan dan konseling terdapat beberapa layanan, salah satunya yaitu layanan konseling kelompok.

Konseling kelompok merupakan pengalamanpengalaman perkembangan dan penyesuaian rutin yang disediakan dalam lingkup kelompok. Konseling kelompok berfokus untuk membantu konseli mengatasi penyesuaian diri sehari-hari mereka, dan menjaga perkembangan dan pertumbuhan pribadi tetap pada koridor yang benar dan sehat. ( Robert, 2016: 52)

Layanan konseling kelompok dalam bimbingan dan konseling dapat meningkatkan motivasi siswa dalam pembelajaran untuk terus melaksanakan kewajibannya sebagai seorang pelajar dan menggapai cita-citanya. Diantaranya dengan memberikan dorongan dan perhatian kepada peserta didik untuk terus belajar dan tidak mengorbankan sekolahnya karena kurangnya motivasi terhadap mereka. Itulah beberapa hal yang harus di perhatikan dalam proses bimbingan dan konseling.

Penelitian Naning Dwi Setyo Astuti (2015) meningkatkan motivasi belajar siswa melalui layanan konseling kelompok dimana terlihat adanya peningkatan motivasi belajar yang tercermin dalam hasil belajar siswa dibandingkan dengan motivasi belajar siswa pada waktu pra tindakan. Pemberian layanan tindakan konseling kelompok yang diberikan pada siswa telah membuat siswa menjadi termotivasi untuk melakukan kegiatan belajarnya baik secara terbimbing maupun belajar secara mandiri di rumah. Dari hasil belajar siswa sebelum tindakan mendapatkan rata-rata 68,09 dan hasil belajar siswa setelah tindakan mendapat rata-rata 79,90.

Berdasarkan hasil observasi awal yang peneliti lakukan di SMP Negeri 1 Pulau Laut Tanjung Selayar dengan melakukan wawancara dengan guru bimbingan dan konseling sekaligus wali kelas VIII. Motivasi belajar siswa pada anak nelayan kelas VIII di Kecamatan Pulau Laut Tanjung Selayar terlihat rendah apalagi pada saat musim penghasilan ikan yang meningkat. Sebagian besar siswa yang jarang hadir ke sekolah adalah anak nelayan karena kelelahan dan kurang tidur. Dampak yang terjadi pada sebagian siswa tersebut yaitu turunnya prestasi, banyak ketinggalan pelajaran, kehadiran bermasalah. Hasil diatas menunjukkan bahwa adanya masalah pada motivasi belajar anak nelayan di Kecamatan Pulau Laut Tanjung Selayar.

Wilayah Kabupaten Kotabaru Kalimantan Selatan terdapat banyak hamparan pesisir pantai. Salah satunya berada di wilayah Kecamatan Pulau Laut Tanjung Selayar tepatnya di Desa Tanjung Pelayar. Pada daerah pesisir pantai mayoritas penduduknya bermata pencaharian sebagai nelayan, termasuk pada desa Tanjung Pelayar. Di Desa Tanjung Pelayar juga tidak sedikit anak-anak pelajar yang ikut membantu orang tuanya bekerja sebagai nelayan.

Nelayan pada umumnya jika turun ke laut, berangkat sore kembali ke darat pada pagi hari atau berangkat subuh dan kembali pada sore hari. Jika anak-anak pelajar yang ikut membantu orang tuanya pergi ke laut seperti waktu-waktu pada umumnya, tentu akan menghambat proses belajar bagi anak serta kurangnya motivasi belajar pada dirinya. Anak tidak akan fokus mengikuti pelajaran di sekolah bahkan anak bisa tidak turun sekolah karena mengantuk akibat pulang pagi dari melaut dan waktu belajarnya pun juga tidak teratur karena kelelahan.

Terlihat bahwa rendahnya motivasi belajar pada anak nelayan di Kecamatan Pulau Laut Tanjung Selayar. Tentu hal-hal tersebut akan menghambat proses pembelajaran di sekolah maupun di luar sekolah. Agar tercapai tujuan pembelajaran didalam proses belajar harus di dukung oleh individu yang bersangkutan. Untuk itu, didalam peningkatan motivasi belajar pada siswa dilakukan dengan cara

Dipublikasikan Oleh :

UPT Publikasi dan Pengelolaan Jurnal

Universitas Islam Kalimantan Muhammad Arsyad Al-Banjari Banjarmasin 


\section{Dina Aida Audria ${ }^{1}$, Sultani $^{2}$, Didi Susanto ${ }^{3}$ \\ Jurnal Mahasiswa BK An-Nur : Berbeda, Bermakna, Mulia \\ Volume 7 Nomor 1 Tahun 2021 \\ Tersedia Online: https://ojs.uniska-bjm.ac.id/index.php/AN-NUR \\ p-ISSN. 2460-9722 | e-ISSN. 2622-8297}

menggunakan konseling kelompok pada anak nelayan. Dalam pelaksanaan konseling kelompok ini, diharapkan dapat menjadi solusi untuk permasalahan para anak nelayan.

Sehubungan dengan permasalahan diatas, sehingga perlu dilakukan motivasi belajar dengan kegiatan konseling kelompok pada anak nelayan di Kecamatan Pulau Laut Tanjung Selayar dalam motivasi belajar akan menghasilkan gambaran motivasi bagi setiap individu. Sehingga judul penelitian ini adalah Upaya Guru Bimbingan dan Konseling dalam Memotivasi Belajar Anak Nelayan Di SMP Negeri 1 Pulau Laut Tanjung Selayar.

\section{METODE}

Penelitian ini adalah penelitian kualitatif, desain yang digunakan dalam penelitian ini adalah fenomenologi. Fenomenologi merupakan suatu penelitian yang bersifat kualitatif, fenomena meliputi suatu cakupan ontologis yang bervariasi meliputi objek, keadaan, proses, dan peristiwa. Studi Fenomenologi menekankan makna dari pengalamanpengalaman sejumlah individu.

Berdasarkan dalam penelitian ini yang dilaksanakan dengan menggunkan penelitian kualitatif dengan desain penelitian fenomenologi yang telah ditentukan, penelitian ini akan menekankan keadaan, peristiwa yang dilakukan sehari-hari atau pengalaman-pengalaman yang dialami siswa seorang anak nelayan yang memiliki motivasi belajar yang rendah pada kelas VIII C SMP Negeri 1 Pulau Laut Tanjung Selayar.

Teknik yang digunakan dalam pengumpulan data pada penelitian ini yaitu teknik wawancara. Teknik wawancara dilakukan untuk mendapatkan data dengan melakukan wawancara secara langsung dengan informan. Penelitian ini melakukan wawancara dengan guru wali kelas yang sekaligus menjadi guru BK kelas VIII SMP Negeri 1 Pulau Laut Tanjung Selayar dan siswa kelas VIII C SMP Negeri 1 Pulau Laut Tanjung Selayar yang motivasi belajarnya rendah.

\section{HASIL DAN PEMBAHASAN}

Gambaran Umum SMP Negeri 1 Pulau Laut Tanjung Selayar

SMP Negeri 1 Pulau Laut Tanjung Selayar merupakan Sekolah Menengah Pertama yang berdiri di Desa Tanjung Pelayar Kecamatan Pulau Laut Tanjung Selayar Kabupaten Kotabaru. SMP Negeri 1 Pulau Laut Tanjung Selayar berada di Jl. Abdullah Kamp. Bugis Rt.01 Desa Tanjung Pelayar Kecamatan
Pulau Laut Tanjung Selayar Kabupaten Kotabaru Provinsi Kalimantan Selatan.

SMP Negeri 1 Pulau Laut Tanjung Selayar memiliki 15 ruangan yang terdiri dari 9 ruang kelas, 1 ruang guru/kantor, 1 tempat penyimpanan alat olahraga, 1 tempat komputer, 1 perpustakaan, dan 2 kamar wc. Ruang kelas yang berjumlah 9 untuk kelas VII A, VII B, VII C, VIII A, VIII B, VIII C, XI A, XI B, dan XI C. Ada juga 1 lapangan untuk dipakai berbagai macam jenis olahraga, seperti bola voly, sepak takraw ataupun senam.

Pada keseluruhan pengajar di SMP Negeri 1 Pulau laut Tanjung Selayar berjumlah 16 orang termasuk 1 kepala sekolah dan 2 orang sebagai penjaga sekolah. Khususnya pada Kelas VIII C yang peneliti jadikan subjek penelitian di SMP Negeri 1 Pulau Laut Tanjung Selayar ada 8 guru mata pelajaran yang masuk mengajar ke kelas termasuk wali kelas VIII C.

\section{Temuan Penelitian}

Peneliti telah melakukan observasi awal di SMP Negeri 1 Pulau Laut Tanjung Selayar dengan melakukan wawancara dengan guru bimbingan dan konseling sekaligus wali kelas VIII C. Guru mengatakan bahwa motivasi belajar siswa pada anak nelayan kelas VIII C di SMP Negeri 1 Kecamatan Pulau Laut Tanjung Selayar terlihat rendah apalagi pada saat musim penghasilan ikan yang meningkat. Sebagian besar siswa yang jarang hadir ke sekolah adalah anak nelayan karena kelelahan dan kurang tidur. Dampak yang terjadi pada sebagian siswa tersebut yaitu turunnya prestasi, banyak ketinggalan pelajaran, dan kehadiran bermasalah. Hasil diatas menunjukkan bahwa adanya masalah pada motivasi belajar anak nelayan di Kecamatan Pulau Laut Tanjung Selayar.

Observasi yang peneliti laksanakan tidak bisa terpenuhi sebagaimana mestinya karena berbagai macam kondisi yang berdampak pada sekolah yang harus di liburkan sehingga tidak ada kegiatan belajar mengajar yang berlangsung selama waktu yang belum di tentukan. Hasil observasi yang telah peneliti laksanakan sebelumnya tidak dapat peneliti lanjutkan dengan observasi kembali, karena kondisi yang belum stabil peneliti hanya bisa melanjutkan penelitian dengan wawancara mendalam kepada beberapa pihak yang berkaitan dengan tema penelitian.

Peneliti melakukan wawancara mendalam kepada beberapa narasumber yang mempunyai pengetahuan berbagai hal yang berkaitan dengan upaya guru bimbingan dan konseling dalam

Dipublikasikan Oleh :

UPT Publikasi dan Pengelolaan Jurnal

Universitas Islam Kalimantan Muhammad Arsyad Al-Banjari Banjarmasin 


\section{Dina Aida Audria ${ }^{1}$, Sultani $^{2}$, Didi Susanto ${ }^{3}$ \\ Jurnal Mahasiswa BK An-Nur : Berbeda, Bermakna, Mulia \\ Volume 7 Nomor 1 Tahun 2021 \\ Tersedia Online: https://ojs.uniska-bjm.ac.id/index.php/AN-NUR \\ p-ISSN. 2460-9722 | e-ISSN. 2622-8297}

memotivasi belajar anak nelayan kelas VIII C di SMP Negeri 1 Pulau Laut Tanjung Selayar. Setelah melakukan penelitian, peneliti memperoleh hasil yang akan diuraikan berikut sesuai dengan judul penelitian yaitu upaya guru bimbingan dan konseling dalam memotivasi belajar anak nelayan kelas VIII C di SMP Negeri 1 Pulau Laut Tanjung Selayar dan rumusan masalah yang telah ditetapkan yaitu gambaran motivasi belajar anak nelayan di SMP Negeri 1 Pulau Laut Tanjung Selayar, faktor rendahnya motivasi belajar anak nelayan di SMP Negeri 1 Pulau Laut Tanjung Selayar, upaya guru bimbingan dan konseling dalam meningkatkan motivasi belajar anak nelayan di SMP Negeri 1 Pulau Laut Tanjung Selayar.

Berikut uraian yang telah dibuat peneliti yang lebih memperjelas jawaban dari rumusan masalah yang sudah ditetapkan dengan memperinci hasil penelitian.

1. Gambaran motivasi belajar anak nelayan di SMP Negeri 1 Pulau Laut Tanjung Selayar

Motivasi belajar adalah dorongan internal dan eksternal pada siswa yang sedang belajar untuk mengadakan perubahan tingkah laku, pada umumnya dengan beberapa indikator atau unsur yang mendukung. Indikator tersebut seperti adanya hasrat dan keinginan berhasil, adanya dorongan dan kebutuhan dalam belajar, adanya cita-cita masa depan, adanya penghargaan dalam belajar, adanya kegiatan yang menarik dalam belajar, adanya lingkungan belajar yang kondusif, sehingga memungkinkan siswa dapat belajar dengan baik.

Motivasi belajar pada anak nelayan maupun yang bukan anak nelayan tetaplah sama, yang membedakan hanya pekerjaan orang tua yang mempengaruhi pola hidup anak dalam keseharian maupun proses pembelajaran. Perbedaan tersebut akan sangat mempengaruhi proses pembelajaran apabila anak tidak terdorong maupun didorong dari luar dan dalam dirinya untuk itu perlu melakukan motivasi belajar siswa.

Motivasi belajar pada anak nelayan siswa kelas VIII C di SMP Negeri 1 Pulau Laut Tanjung Selayar mengalami pengurangan motivasi, dilihat dari tingkah laku siswa dalam proses pembelajaran di kelas, ketidakhadiran siswa, dan nilai siswa yang tidak memuaskan, seperti menurut narasumber bernama ibu Rusnelly sebagai wali kelas sekaligus guru BK di kelas VIII C SMP Negeri 1 Pulau Laut Tanjung Selayar:

"Siswa tidak semangat dalam mengikuti pembelajaran, tidak fokus memperhatikan guru dalam

Dipublikasikan Oleh :

UPT Publikasi dan Pengelolaan Jurnal

Universitas Islam Kalimantan Muhammad Arsyad Al-Banjari Banjarmasin penyampaian materi dan berakibat pada nilai siswa

Hal serupa juga di katakan oleh ibu Rusma guru bahasa inggris:

" Siswa sangat sulit memahami pelajaran, siswa tidak semangat dalam mengikuti pembelajaran, tidak fokus memperhatikan jika guru mnyampaikan materi dan bahkan kalau ibu melempar pertanyaan dia tidak bisa menjawab bahkan terlihat bingung dengan yang ibu tanyakan"

Sama juga dengan yang dikatakan oleh guru matematika ibu Halimatus Sa'diyah:

"Dalam pelajaran matematika menurut ibu mereka lumayan mengalami motivasi belajar yang rendah"

Dari hasil temuan dapat di jelaskan bahwa gambaran motivasi belajar siswa yang merupakan anak nelayan kelas VIII C mengalami motivasi belajar yang rendah, bisa dilihat dari beberapa siswa yang sangat sulit memahami pelajaran yang dijelaskan oleh guru mata pelajaran, tidak adanya antusias siswa dalam mengikuti proses belajar dikelas dan siswa mengalami kesulitan saat guru memberikan pertanyaan.

\section{Faktor rendahnya motivasi belajar anak nelayan di SMP Negeri 1 Pulau Laut Tanjung Selayar}

Rendahnya motivasi belajar dapat dipengaruhi berbagai macam faktor, seperti kehidupan sehari-hari, pekerjaan orang tua, pola hidup di masyarakat dan pergaulan seseorang tersebut. Pada penelitian ini faktor yang mempengaruhi motivasi belajar anak nelayan kelas VIII C di SMP Negeri 1 Pulau Laut Tanjung Selayar adalah pekerjaan orang tua siswa sebagai nelayan. Faktor tersebut mempengaruhi motivasi belajar karena siswa tersebut membantu orang tuanya bekerja dan sulit membagi waktunya untuk beristirahat maupun belajar. Seperti yang di sampaikan narasumber ibu Rusnelly yaitu:

"Ibu lihat dari beberapa siswa yang orang tuanya mencari nafkah sebagai nelayan, siswa mengalami motivasi belajar yang rendah karena siswa tersebut sering ikut membantu orang tuanya sehingga pada saat pembelajaran siswa kurang semangat karena lelah dan berpengaruh pada proses pembelajaran siswa bahkan tidak jarang siswa tersebut tidak turun sekolah"

Begitupun dari hasil wawancara yang dikatakan oleh ibu Rusma sebagai guru bahasa inggris:

"Menurut ibu, banyak faktor yang mempengaruhi hal tersebut, seperti tidak ada dorongan atau kesadaran belajar dari diri mereka sendiri dan juga mungkin tidak ada dorongan dari orang tua, Ibu perhatikan juga yang rendah," 


\section{Dina Aida Audria ${ }^{1}$, Sultani $^{2}$, Didi Susanto ${ }^{3}$ \\ Jurnal Mahasiswa BK An-Nur : Berbeda, Bermakna, Mulia \\ Volume 7 Nomor 1 Tahun 2021 \\ Tersedia Online: https://ojs.uniska-bjm.ac.id/index.php/AN-NUR \\ p-ISSN. 2460-9722 | e-ISSN. 2622-8297}

dari siswa-siswa yang motivasi belajar rendahnya sangat menonjol di kelas itu orang tuanya bekerja sebagai pelaut atau nelayan"

Lalu menurut ibu Halimatus Sa'diyah sebagai guru matematika:

"Menurut ibu, faktor utamanya mungkin karena ini pelajaran matematika dan mereka berpikir kalau ini sulit jadi otomatis motivasi belajar mereka juga kurang pada pelajaran ini, untuk pekerjaan orang tua bisa saja mempengaruhi tapi tergantung juga dari siswa itu sendiri"

Dari hasil temuan di atas, faktor rendahnya motivasi belajar anak nelayan dapat dipengaruhi oleh pekerjaan orang tua, itu terjadi karena anak tersebut membantu orang tuanya sehingga anak tidak dapat mengatur waktu belajar. Faktor lain yang mempengaruhi juga berasal dari diri anak tersebut bagaimana dia menganggap penting atau tidaknya proses pembelajaran.

Faktor yang mempengaruhi motivasi belajar anak nelayan yang rendah juga diutarakan oleh siswa yang peneliti juga wawancarai, seperti yang di sampaikan oleh siswa yang bernama Siniansya:

" Nilai saya rendah dan sulit memperhatikan guru pada saat pembelajaran karena mengantuk bu, saya membantu orang tua pergi melaut, jadi malamnya saya begadang"

Sama halnya dengan Siniansya, putra juga mengatakan hal yang serupa:

“ Saya sangat mengantuk bu jadi tidak bisa memperhatikan pelajaran di kelas karena malam sebelumnya saya begadang bu karena membantu orang tua"

Dari hasil temuan, siswa yang motivasi belajarnya rendah di kelas VIII C SMP Negeri 1 Pulau Laut Tanjung selayar itu terjadi karena siswa tersebut membantu orang tuanya sebagai nelayan sehingga siswa harus begadang dan mengalami kelelahan sehingga pada saat belajar di kelas tidak fokus dan tidak bisa mengikuti pelajaran dengan baik.

\section{Upaya guru bimbingan dan konseling dalam meningkatkan motivasi belajar anak nelayan di SMP Negeri 1 Pulau Laut Tanjung Selayar}

Guru bimbingan dan konseling memiliki peranan penting dalam meningkatkan motivasi belajar siswa, untuk itu perlu adanya upaya yang dilakukan guru bimbingan dan konseling dalam meningkatkan motivasi belajar pada siswa. Hal ini perlu dilakukan untuk mendorong siswa menjadi pelajar yang bisa mempunyai cita-cita kedepannya dengan tekun belajar sejak dini.
Pada penelitian ini, upaya dilakukan guru bimbingan dan konseling dalam meningkatkan motivasi belajar anak nelayan siswa kelas VIII C di SMP Negeri 1 Pulau Laut Tanjung Selayar adalah dengan melakukan konseling kelompok kepada 8 orang siswa yang memiliki motivasi belajar rendah. Seperti yang disampaikan ibu Rusnelly sebagai guru bimbingan dan konseling yaitu:

"Sebagai guru sekaligus wali kelas VIII upaya yang dilakukan untuk meningkatkan motivasi belajar siswa yaitu dengan terus motivasi dengan memberikan masukan penyemangat belajar dan juga dengan melaksanakan kenseling kelompok pada siswa yang motivasi belajarnya rendah".

Begitu juga dengan yang disampaikan guru mata pelajaran ibu Rusma dan Ibu Halimatus Sa'diyah:

"Kalau saya sebagai guru mata pelajaran, saya hanya memberikan motivasi dengan ceramah di kelas memberikan mereka kata-kata bijak supaya terus semangat belajar, kalau untuk guru bimbingan dan konseling ibu tidak terlalu tau tapi ibu pernah bertanya kepada siswa dan kadang ibu melihat apa yang dilakukan siswa di kelas untuk meningkatkan motivasi belajar siswa yaitu guru memberikan motivasi mendalam dengan memberikan masukan penyemangat belajar dan juga mereka pernah melaksanakan kenseling kelompok pada siswa yang motivasi belajarnya rendah"

": Kalau saya sebagai guru mata pelajaran, saya selalu memberikan motivasi dan juga di dalam kelas terkadang saya memberi kuis yang menyenangkan untuk mereka supaya tidak suntuk di kelas dan semangat belajar. Kalau dari guru bimbingan dan konseling, setau saya upaya yang di lakukan guru bimbingan dan konseling atau bisa dibilang wali kelas dari kelas VIII C hanya dengan memotivasi langsung atau dengan sekali dua kali pemberian layanan konseling kelompok yang belum sesuai dengan standar konseling kelompok yang seharusnya"

Temuan di atas menunjukkan bahwa upaya guru bimbingan dan konseling di SMP Negeri 1 Pulau Laut Tanjung Selayar untuk meningkatkan motivasi belajar siswa adalah dengan terus memotivasi siswa secara mendalam dan dengan melaksakan konseling kelompok yang seadanya sesuai dengan pengetahuan guru bimbingan dan konseling karena guru bimbingan dan konseling kelas VIII C di SMP Negeri 1 Pulau Laut Tanjung Selayar hanyalah wali kelas yang merangkap sebagai guru bimbingan dan konseling yang bukan merupakan sarjana guru bimbingan dan konseling.

Dipublikasikan Oleh : 


\section{Dina Aida Audria ${ }^{1}$, Sultani ${ }^{2}$, Didi Susanto ${ }^{3}$ \\ Jurnal Mahasiswa BK An-Nur : Berbeda, Bermakna, Mulia \\ Volume 7 Nomor 1 Tahun 2021}

Tersedia Online: https://ojs.uniska-bjm.ac.id/index.php/AN-NUR

p-ISSN. 2460-9722 | e-ISSN. 2622-8297

Pelaksanaan layanan konseling kelompok untuk memotivasi belajar siswa di SMP Negeri 1 Pulau Laut Tanjung Selayar yang di laksanakan di Kelas VIII C di ikuti oleh 8 orang siswa yang pekerjaan orang tuanya sebagian besar sebagai nelayan dan siswa tersebut memiliki motivasi belajar yang rendah. Berikut adalah tabel siswa sebagai anak nelayan yang mengikuti layanan konseling kelompok:

\section{Tabel 1}

Siswa yang mengikuti Layanan Konseling Kelompok mengenai Motivasi Belajar Kelas VIII C SMP Negeri

1 Pulau Laut Tanjung Selayar

\begin{tabular}{|c|l|c|l|c|}
\hline $\begin{array}{c}\text { N } \\
\mathrm{o}\end{array}$ & \multicolumn{1}{|c|}{ Nama } & $\begin{array}{c}\text { Jenis } \\
\text { Kelami } \\
\mathrm{n}\end{array}$ & Alamat & $\begin{array}{l}\text { Pekerjaa } \\
\text { n Ortu }\end{array}$ \\
\hline 1 & $\begin{array}{l}\text { Adrian } \\
\text { Pahrullah }\end{array}$ & $\mathrm{L}$ & $\begin{array}{l}\text { Tg. } \\
\text { Tengah }\end{array}$ & Nelayan \\
\hline 2 & $\begin{array}{l}\text { Agus } \\
\text { Fahrie }\end{array}$ & L & $\begin{array}{l}\text { Tg. } \\
\text { Pelayar }\end{array}$ & Tukang \\
\hline 3 & Heri & L & $\begin{array}{l}\text { Tg. } \\
\text { Pelayar }\end{array}$ & - \\
\hline 4 & Riswar & L & $\begin{array}{l}\text { Tg. } \\
\text { Sungkai }\end{array}$ & Nelayan \\
\hline 5 & Putra & L & $\begin{array}{l}\text { Tg. } \\
\text { Sungkai }\end{array}$ & Nelayan \\
\hline 6 & Siniansya & L & $\begin{array}{l}\text { Tg.Tenga } \\
\text { h }\end{array}$ & Nelayan \\
\hline 7 & Suaib & L & $\begin{array}{l}\text { Tg.Tenga } \\
\text { h }\end{array}$ & Nelayan \\
\hline 8 & $\begin{array}{l}\text { Syahriann } \\
\text { ur }\end{array}$ & L & $\begin{array}{l}\text { Tg. } \\
\text { Sungkai }\end{array}$ & - \\
\hline
\end{tabular}

Anak nelayan yang mengikuti layanan konseling kelompok seperti tabel di atas, mengalami perubahan setelah melaksanakan layanan konseling kelompok tersebut. Seperti yang di sampaikan oleh wali kelas atau guru bimbingan dan konseling di kelas VIII C dan guru mata pelajaran serta penyampaian dari siswa yang mengalami motivasi belajar yang rendah yang telah melaksanakan layanan konseling kelompok.

"Menurut saya sebagai wali kelas yang juga sebagai guru bimbingan dan konseling, ada peningkatan motivasi belajar dilihat dari antusias siswa mengikuti pembelajaran di kelas dan nilai siswa yang mengalami peningkatan

"Menurut saya sebagagai guru mata pelajaran yang mengajar bahasa inggris, setelah pelaksanaan konseling kelompok dengan motivasi mendalam dari wali kelas yang sekaligus guru bk di kelas VIII C ada peningkatan motivasi belajar dilihat dari pemahaman siswa dalam pelajaran bahasa inggris, dan jika diberi pertanyaan mereka juga sebagian besar bisa menjawab dengan benar"

"Menurut saya sebagai guru matematika di kelas VIII C, setelah pemberian motivasi tersebut dan pelaksanaan konseling kelompok dengan motivasi mendalam dari wali kelas yang sekaligus guru bk di kelas VIII C ada perubahan yang terjadi dari motivasi belajar dilihat dari pemahaman siswa dalam proses belajar di kelas, antusiannya dalam mengikuti pembelajaran dan jika diberi pertanyaan mereka juga beberapa bisa menjawab dengan benar"

Dari hasil temuan di atas menunjukkan bahwa upaya guru bimbingan dan konseling untuk meningkatkan motivasi belajar anak nelayan di kelas VIII C SMP Negeri 1 Pulau Laut Tanjung Selayar dengan pemberian motivasi mendalam dan melaksanakan layanan konseling kelompok dapat meningkatkan motivasi belajar siswa dengan beberapa perubahan seperti siswa lebih paham pada pembelajaran, siswa lebih antusias mengikuti proses belajar dan siswa juga bisa menjawab apabila guru memberikan pertanyaan pada siswa tersebut, sama halnya dengan yang di katakan siswa yang orang tuanya sebagai anak nelayan yang memiliki motivasi belajar yang rendah yang telah melaksanakan konseling kelompok, bahwa siswa merasa mengalami perubahan pemahaman tentang belajar dan di buktikan dari tingkah laku siswa tersebut. Berikut yang dikatakan Nian dan Putra:

"Saya merasa motivasi belajar saya kurang bu, saya tidak bisa mengatur waktu belajar dengan baik, saat di kelas tidak memperhatikan pelajaran, sering mengantuk bu bahkan saya sering tidak turun sekolah. Setelah melaksanakan konseling kelompok saya merasa perlahan-lahan bisa mengatur waktu belajar, berusaha untuk mengatur tidur supaya tidak mengantuk di sekolah dan tetap megoptimalkan belajar walaupun juga membantu orang tua"

"Saya merasa perlahan bisa mengatur waktu belajar, berusaha untuk mengatur tidur supaya tidak mengantuk di sekolah dan tetap berusaha meluangkan waktu belajar dan juga tetap membantu orang tua"

Dari temuan diatas menunjukkan bahwa, siswa yang telah melakukan layanan konseling kelompok bisa lebih menyadari bahwa belajar adalah hal yang penting dilakukan sebagai seorang pelajar, mereka juga lebih memperhatikan waktu belajar dan sebisa mungkin mengatur waktu belajar, waktu istirahat dan juga terutama tetap membantu orang tua. 


\section{PENUTUP}

Berdasarkan penegasan judul dan latar belakang tersebut, maka masalah penelitiannya adalah tentang gambaran motivasi belajar anak nelayan di Kecamatan Pulau Laut Tanjung Selayar, faktor yang menyebabkan rendahnya motivasi belajar anak nelayan di SMP Negeri 1 Pulau Laut Tanjung Selayar, dan upaya guru bimbingan dan konseling dalam meningkatkan motivasi belajar anak nelayan di SMP Negeri 1 Pulau Laut Tanjung Selayar.

Berdasarkan penelitian upaya guru bimbingan dan konseling dalam memotivasi belajar anak nelayan kelas VIII C yang di laksanakan di SMP Negeri 1 Pulau Laut Tanjung Selayar dengan menggunakan Teori Maslow, sebagai berikut:

1. Motivasi belajar yang rendah pada siswa dilihat dari kurang aktifnya dalam mengikuti pembelajaran, tidak memperhatikan guru saat memaparkan materi di dalam kelas, terlihat mengantuk di kelas, kurang semangat mengikuti pembelajaran, kehadiran yang tidak diperhatikan, waktu belajar yang tidak diperhatikan baik di sekolah maupun di rumah dan berakibat pada nilai siswa yang mengalami penurunan.

2. Faktor yang menyebabkan rendahnya motivasi belajar anak nelayan dilihat dari siswa mengalami motivasi belajar yang rendah karena siswa tersebut sering ikut membantu orang tuanya sehingga pada saat pembelajaran siswa kurang semangat karena lelah dan berpengaruh pada proses pembelajaran siswa bahkan kadang siswa tersebut tidak turun sekolah.

Rendahnya motivasi belajar berakar dari siswa yang mengalami kelelahan dan menjadi kebutuhan pada dirinya kurang diperhatikan seperti makan tidak teratur, tidur teratur dan belajar juga tidak teratur. Kelelahan juga membuatnya menjadi tidak nyaman, merasa tidak ada yang memperhatikan serta faktor orang tua seorang nelayan membuatnya tidak terlalu bergaul dengan yang lain dan menjadi kurang percaya pada dirinya sendiri.

3. Upaya guru bimbingan dan konseling dalam meningkatkan motivasi belajar anak nelayan adalah dengan melakukan konseling kelompok pada siswa yang motivasi belajarnya rendah. Layanan konseling kelompok diikuti oleh 8 orang siswa yang motivasi belajarnya rendah dan sebagian besar orang tuanya bekerja sebagai nelayan.

4. Hasil wawancara, siswa mengatakan bahwa setelah melakukan konseling kelompok membuatnya semakin sadar pentingnya belajar dan perlunya mengatur waktu pada dirinya sendiri, memperhatikan pola makan, pola tidur maupun belajarnya, juga membantu orang tuanya bekerja dan menyadari kalau orangorang disekitarnya baik kepadanya tanpa memandang pekerjaan orang tuanya.

Kesimpulannya adalah upaya yang dilakukan guru bimbingan dan konseling meningkatkan motivasi belajar siswa dapat dilakukan dengan layanan konseling kelompok. Siswa yang mengalami motivasi belajar rendah di kelas VIII SMP Negeri 1 Pulau Laut Tanjung Selayar, menurut peneliti sudah baik dan mengalami peningkatan belajar setelah melaksanakan konseling kelompok.

\section{REFERENSI}

Ahmadi, Rulam. (2016). Metodologi Penelitian Kualitatif. Yogyakarta: Ar-ruz Media.

A.M, Sardiman. (2016). Interaksi \& Motivasi Belajar Mengajar. Jakarta: PT Raja Grafindo Persaja.

Astati. (2016). Upaya Peningkatan Motivasi Belajar Siswa Pada Pembelajaran Matematika Dan Bahasa Indonesia Melalui Pendekatan Pembelajaran Konstektual. Jurnal Ilmu Pendidikan Sosial, Sains, dan Humaniora, Vol 2 No 1.

Astuti, N.D.S. (2015). Meningkatkan Motivasi Belajar Melalui Layanan Konseling Kelompok. Jurnal Penelitian Tindakan Bimbingan dan Konseling, Vol 1 No 1.

Djumali. (2013). Meningkatkan Motivasi Belajar Siswa Melalui Penggunaan Strategi Pembelajaran Index card Match Dalam Pembelajaran IPS Kelas VIII B SMP Negeri 2 Sawit Boyolali. Jurnal Pendidikan Ilmu Sosial, Vol 23 No 1.

Emda, Amna. (2017). Kedudukan Motivasi Belajar Siswa Dalam Pembelajaran. Jurnal Lantanida, Vol 5 no 2.

Fauziah, Safiah, I \& Habibah, S. (2017). Upaya meningkatkan Motivasi Belajar Siswa Melalui Lesson Study Di Kelas V SD Negeri Lampagen Aceh Besar. Jurnal Ilmiah Pendidikan Guru Sekolah Dasar, Vol 2 No 1.

Dipublikasikan Oleh :

UPT Publikasi dan Pengelolaan Jurnal

Universitas Islam Kalimantan Muhammad Arsyad Al-Banjari Banjarmasin 
Jurnal Mahasiswa BK An-Nur : Berbeda, Bermakna, Mulia

Volume....Nomor....., Tahun

Tersedia Online: https://ojs.uniska-bjm.ac.id/index.php/AN-NUR

p-ISSN. 2460-9722

e-ISSN. 2622-8297

Gibson, R. L \& Mitchell M. N. (2016). Bimbingan dan Konseling Edisi Ketujuh. Yogyakarta: Pustaka Pelajar.

Harmalis. (2019). Motivasi Belajar Dalam Perspektif Islam. Indonesian Journal of Counseling \& Development, Vol 1 No 1.

Kurniawan. (2017). Upaya Meningkatkan Motivasi Belajar Siswa Menggunakan Media Gambar. Jurnal Pendidikan Guru Sekolah Dasar Edisi 1.

Maliasih, Hartono \& P. Nurani. (2017). Upaya Meningkatkan Motivasi Belajar dan Hasil Belajar Kognitif Melalui Metode Teams Games Tournaments dengan Strategi Peta Konsep Pada Siswa SMA. Jurnal Profesi Keguruan, Vol 3 No 2.

Penulis, Tim. (2019). Pengantar Pendidikan. Banjarmasin: Universitas Lambung Mangkurat.

Saidah, U.H. (2016). Pengantar Pendidikan Tealaah Pendidikan Secara Global dan Nasional. Jakarta: PT Raja Grafindo Persaja.

Sulistyo, Ignatius. (2016). Peningkatan Motivasi Belajar Dengan Menerapkan Model Pembelajaran Kooperatif TGT Pada Pelajaran PKN. Jurnal Studi Sosial, Vol 4 No 1.

Suprihatin, S. (2015). Upaya Guru Dalam Meningkatkan Motivasi Belajar Siswa. Jurnal Pendidikan Ekonomi, Vol 3 No 1.

Syahril, S. (2017). Motivasi Belajar Dalam Perspektif Hadits. Jurnal Al- Taujih Bingkai Bimbingan dan Konseling Islami, Vol 3 No 2.

Tsuroyya, Elfa. (2017). Peningkatan Motivasi Belajar Siswa Melalui Strategi Gubah Lagu. Jurnal Pendidikan Madrasah, Vol 2 No 1.

Umar, Husein. (2011). Metode Penelitian untuk Skripsi dan Tesis Bisnis. Jakarta: Rajawali Pers.

Uno, Hamzah B. (2019). Teori Motivasi dan Pengukurannya. Jakarta: PT Bumi Aksara.

Dipublikasikan Oleh :

UPT Publikasi dan Pengelolaan Jurnal

Universitas Islam Kalimantan Muhammad Arsyad Al-Banjari Banjarmasin 